\title{
Pengembangan Permainan Edukatif Ragam Budaya Nusantara Berbasis Android
}

\author{
Dony Defrianto, Rinta Kridalukmana, Ike Pertiwi Windasari \\ Program Studi Sistem Komputer Fakultas Teknik Universitas Diponegoro \\ Jalan Prof. Sudharto, Tembalang, Semarang, Indonesia \\ Defrianto.dony@gmail.com
}

\begin{abstract}
This research aims to develop a game software that can be used as an alternative means of learning media in Indonesian local culture for the community in the form of the game in the Android operating system.

The methodology used in this study is the Multimedia Development Life Cycle (MDLC) sourced from Luther and has been modified by Sutopo, which consists of six stages, namely the concept, design, collection of material, manufacture, testing, and distribution. Testing applications that have been created using black-box method, which is carried out to check the functions contained in the application. The process of application testing is done by using a questionnaire. The testing is done objectively by asking ratings from users of the application.

Therefore, the results of the study that were obtained using black-box method, indicates that the game is already working according to specifications needed to show test results for each application functions and buttons. And the results of the questionnaire data obtained by the average score of all ratings amounted to $84 \%$. And it can be concluded that the applications made are well-qualified.
\end{abstract}

Keywords: Games, Software, MDLC, Black-box, Questionnaire.

\section{PENDAHULUAN}

$\mathrm{B}$ angsa Indonesia merupakan bangsa majemuk yang terdiri dari berbagai suku bangsa, agama dan bahasa. Kemajemukan bangsa Indonesia merupakan salah satu kekayaan bangsa Indonesia yang jarang dimiliki oleh negara-negara lain di dunia. Masing-masing suku bangsa di Indonesia mempunyai adat-istiadat dan kebudayaan khusus tersendiri di setiap daerah yang menjadi identitasnya. Berdasarkan hasil sensus penduduk Badan Pusat Statistika ${ }^{[11]}$ terdapat 1.340 suku bangsa yang tersebar di Indonesia.

Teknologi di masa kini memberikan pengaruh yang sangat besar terhadap perkembangan masyarakat, menurut lembaga riset GfK Asia tahun 2013, total penjualan smartphone di Indonesia mencapai 14,8 juta unit dengan total transaksi Rp 39,1 triliun. Indonesia memiliki kontribusi $30 \%$ bagi total penjualan smartphone di Asia Tenggara. Dan berdasarkan laporan riset dari StatCounter [16], mengenai pengguna smartphone selama tahun 2014, ternyata Android merupakan sistem operasi yang mendominasi peredaran smartphone di tanah air dengan pembagian pasar sebesar 59,91 persen. Melalui penelitian ini, penulis bermaksud membangun sebuah game interaktif berbasis sistem operasi Android yang bertema Kebudayaan Indonesia, untuk menambah wawasan tentang keragaman budaya kepada masyarakat dengan cara yang menyenangkan dan mudah diserap.
Dengan dilakukannya penelitian ini, diharapkan dapat menjadi salah satu media pembelajaran yang menyenangkan dan mudah dipahami bagi semua kalangan masyarakat, sehingga menggunakan smartphone tidak hanya menggunakannya untuk bermain permainan umum, melainkan ada unsur pendidikan kebudayaan di dalamnya.

\section{DASAR TEORI}

\section{A. Teori Permainan}

Permainan [3] adalah sebuah interaktif, aktivitas yang berpusat pada pencapaian, ada pelaku aktif, dan ada lawan. Bahwa pada dasarnya permainan merupakan proses artistik sehingga seorang desainer permainan harus memperhatikan tidak hanya sisi teknis namun juga harus memperhatikan sisi artistik.

\section{B. Multimedia}

Multimedia ${ }^{[10]}$ adalah suatu kombinasi dari paling sedikit dua media input dan output dari data, media yang didapat audio (suara, musik) animasi video, teks, grafik dan gambar. Elemen-elemen yang terdapat pada multimedia secara umum terbagi atas lima jenis ${ }^{[5]}$, yaitu:

1) Teks : Teks adalah elemen paling dasar dari seluruh program pengolah kata juga aplikasi multimedia. Teks digunakan untuk menjabarkan atau menyampaikan informasi tertentu. Teks tersusun dari beberapa simbol, abjad besar dan kecil, serta angka. Dalam kenyataannya multimedia menyajikan informasi dengan cepat, karena tidak diperlukan membaca secara rinci dan teliti. Kebanyakan sistem multimedia dirancang dengan menggunakan teks karena teks merupakan sarana yang efektif untuk mengemukakan ide-ide dan menyediakan instruksi-instruksi kepada user (pengguna).

2) Grafik (Image) : Grafik merupakan sarana sekaligus elemen multimedia yang berguna untuk mengungkapkan suatu informasi secara visual. Grafik menjadi nilai dan unsur tambah suatu penyajian data. Gambar digunakan dalam presentasi multimedia untuk menarik perhatian dan dapat mengurangi kebosanan, apabila dibandingkan dengan teks. Manusia sangat berorientasi pada visual dan gambar merupakan sarana yang sangat baik untuk menyajikan informasi.

3) Suara (Audio) : Suara adalah elemen paling unik yang tersedia diantara keseluruhan elemen multimedia. Elemen ini menyempurnakan aplikasi multimedia dengan kemampuan audionya. Bila elemen lain memberikan informasi kepada pengguna dengan menggunakan indra penglihatan maka elemen suara 
akan memberikan informasi dan memanjakan pengguna dengan menggunakan indra pendengaran.

4) Video : Video akan membuat aplikasi multimedia lebih hidup. Namun kendala yang dihadapi dalam memanfaatkan media ini adalah ukuran berkas yang terlalu besar. Untuk itu, diperlukan perangkat lunak lain untuk memperkecil ukuran berkas video.

5) Animasi : Animasi adalah urutan gambar atau image yang ditampilkan secara berurutan sehingga akan menimbulkan kesan gambar tersebut bergerak, kesan bergerak ini didapat akibat adanya peralihan dari satu gambar ke gambar lainnya dalam satu satuan waktu yang disebut frame per second (fps) dalam pengertian ada beberapa jumlah frame yang berupa gambar atau image untuk satu detik animasi. Dalam arti lain animasi adalah persepsi yang terjadi akibat perpindahan frame dalam satu waktu

\section{Budaya Nusantara}

Kebudayaan Nasional [9] adalah kebudayaan bangsa Indonesia yang berakar dari kebudayaan daerah. Berdasarkan Amandemen ke-4 Undang-Undang Dasar 1945, disebutkan bahwa negara Indonesia ditengah peradaban dunia dengan menjamin kebebasan masyarakat dalam memelihara budanyanya, tujuan dari adanya kebudayaan nasional itu yaitu sebagai berikut.

1. Alat perekat bangsa

2. Semangat nasionalisme.

3. Identitas Negara

\section{Permainan Edukatif}

Permainan Edukatif [4] yaitu suatu permainan yang bermanfaat untuk menunjang proses tumbuh kembang, dan merupakan cara atau alat pendidikan yang bersifat mendidik bermanfaat untuk meningkatkan kemampuan berfikir. Dalam penyediaan mainan tidaklah harus mahal. Dengan kata lain, permainan edukatif dapat diberikan sejak lahir. Tentu semua menyesuikan dengan tumbuh kembang karena setiap masa memiliki tugas perkembangan masing-masing dan permainan tiap usia berbeda.

Permainan edukatif juga dapat berarti sebuah bentuk kegiatan yang dilakukan untuk memperoleh kesenangan atau kepuasan dari cara atau alat pendidikan yang digunakan dalam kegiatan bermain, yang disadari atau tidak memiliki muatan pendidikan yang dapat bermanfaat dalam mengembangkan diri secara seutuhnya.

\section{E. Sistem Operasi Android}

Android ${ }^{[8]}$ merupakan sebuah sistem operasi perangkat mobile berbasis linux yang mencakup sistem operasi, middleware, dan aplikasi. Beberapa pengertian lain Android, yaitu :

a. Merupakan platorm terbuka (open source) bagi para pengembang (programmer) untuk membuat aplikasi.

b. Merupakan sistem operasi yang dibeli Google Inc. dari Android Inc.

c. Bukan bahasa pemograman, tetapi hanya menyediakan lingkungan hidup atau run time environment yang disebut DVM ( Dalvik Virtual Machine) yang telah di oplimasi untuk alat/Device dengan sistem memori kecil.

Android tersedia secara open source bagi manufaktur perangkat keras untuk memodifikasi sesuai kebutuhan.

\section{F. Construct 2}

Construct $2^{[13]}$ adalah produk buatan Scirra, perusahaan yang berasal dari London, Inggris. Construct 2 yang memang didesain dengan banyak fitur. Game builder ini sebenarnya dirancang untuk game berbasis 2D.

Construct 2 menyediakan 70 visual effect yang menggunakan engine WebGL dan juga dilengkapi dengan 20 built-in plugin dan behaviours (perilaku objek). Dengan begitu pengembang dapat melakukan hal-hal seperti :

a. Menambah sprite animasi,

b. Objek teks,

c. Menambah musik,

d. dan penambahan efek-efek grafis layaknya Adobe

Photoshop.

Pemanggilan fungsi-fungsi di Construct 2 hanya menggunakan pengaturan Events yang telah disediakan. Events merupakan pilihan-pilihan Action dan Kondisi yang akan menjadi nyawa dalam game dan game dapat berjalan sesuai yang kita inginkan.

\section{G. Audacity}

Audacity [6] adalah aplikasi perangkat lunak untuk merekam dan menyunting suara. Aplikasi ini bersifat open source dan sehingga dapat berjalan pada berbagai sistem operasi.

Audacity mampu mengoreksi suara tertentu, atau sekedar menambahkan berbagai efek yang disediakan. Audacity juga digunakan untuk memotong suara, menambahan bahkan mengkonversi ke file lain, diantaranya MP3, Ogg, dan Wave.

Selain itu juga dapat berkreasi dengan suara yang dimiliki sendiri melalui perekam suara.Aplikasi ini sangat ringan dan untuk sekedar konversi file audio cukup handal. Kelebihan dari aplikasi ini adalah fitur dan kestabilan Antar muka yang digunakan juga tidak terlalu banyak dan waktu tunggunya juga tidak terlalu lama.

\section{H. Corel Draw X6}

Corel Draw ${ }^{[14]}$ adalah sebuah program komputer yang melakukan editing pada garis vektor. Program ini dibuat oleh Corel, sebuah perusahaan software yang berkantor pusat di Ottawa, Kanada. Corel draw memiliki kegunaan untuk mengolah gambar, oleh karena itu banyak digunakan pada pekerjaan dalam bidang publikasi atau percetakan ataupun pekerjaan di bidang lain yang membutuhkan proses visualisasi.

Penggunaan Aplikasi CorelDraw dalam Pengembangan Permainan Edukatif Ragam Budaya Nusantara, dengan Fitur Tool box yang merupakan sarana utama pada Corel Draw yakni sebuah kotak (box) penyimpanan berbagai alat (Tool) untuk keperluan membuat objek dasar dari sebuah desain grafis, memberi warna, memodifikasi objek dan menulis teks, memberikan efek-efek interaktif untuk menunjang pengembangan Aplikasi yang akan di rancang.

\section{UML (Unified Modelling Language)}

Pada perkembangan teknik pemrograman berorientasi objek, munculah sebuah standarisasi bahasa pemodelan untuk pembangunan perangkat lunak yang dibangun dengan menggunakan teknik pemrograman berorientasi objek, yaitu Unified Modelling Languange (UML). UML muncul karena adanya kebutuhan pemodelan visual untuk 
menspesifikasikan, menggambarkan, membangun, dan dokumentasi dari sistem perangkat lunak. UML merupakan bahasa visual untuk pemodelan dan komunikasi mengenai sebuah sistem dengan menggunakan diagram dan teks-teks pendukung ${ }^{[2]}$.

UML hanya berfungsi untuk melakukan pemodelan. Jadi penggunaan UML tidak terbatas pada metodologi tertentu, meskipun pada kenyataannya UML paling banyak digunakan pada metodologi berorientasi objek.

\section{J. Skala Likert}

Skala Likert ${ }^{[12]}$ ialah skala yang dapat dipergunakan untuk mengukur sikap, pendapat, dan persepsi seseorang atau sekelompok orang tentang suatu gejala atau fenomena pendidikan. Skala Likert adalah suatu skala psikometrik yang umum digunakan dalam kuesioner, dan merupakan skala yang paling banyak digunakan dalam riset berupa survei. ${ }^{[1]}$

\section{PERANCANGAN SISTEM}

\section{A. Tahap Pengembangan Sistem}

Metodologi yang digunakan dalam penelitian ini adalah Multimedia Development Life Cycle (MDLC) yang bersumber dari Luther dan sudah dimodifikasi oleh Sutopo. Metodologi pengembangan multimedia tersebut terdiri dari enam tahap, yaitu konsep (concept), desain (design), pengumpulan materi (material collecting), pembuatan (assembly), pengujian (testing), dan distribusi (distribution). Keenam tahap ini tidak harus berurutan dalam prakteknya, tahap-tahap tersebut dapat saling bertukar posisi.

Metodologi pengembangan multimedia Luther yang telah dimodifikasi oleh Sutopo ini dapat dilihat pada Gambar 1.

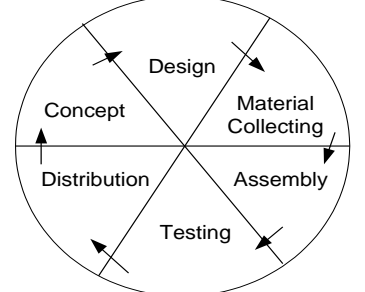

Gambar 1. Tahap pengembangan multimedia menurut Luther yang sudah dimodifikasi Sutopo

\section{B. Konsep}

Aplikasi yang dibuat dalam penelitian tugas akhir ini bertujuan untuk membuat simulasi dalam bentuk permainan edukatif dan mengenalkan kembali keragaman budaya Indonesia kepada masyarakat. Objek penelitian ini memiliki kategori pada jenjang sekolah dasar hingga perguruan tinggi. Pada rentang usia tersebut, seseorang sedang dalam masa aktif belajar sehingga diharapkan tujuan untuk mengenalkan kembali budaya daerah Indonesia ini dapat tersampaikan dengan baik.

Konsep dasar aplikasi ini yaitu menarik dan dapat menjelaskan tentang beberapa pakaian adat daerah Indonesia secara umum. Oleh karena itu digunakan perpaduan teks, suara dan gambar dalam merancang desain aplikasi.

Permainan Edukatif Ragam Budaya Nusantara ini menyajikan tampilan berbagai provinsi yang terdapat di Indonesia, setiap provinsi mempunyai pakaian adat yang berbeda dari provinsi lainnya. untuk ke kolom provinsi berikutnya pengguna harus menyelesaikan misi yang terdapat dikolom provinsi sebelumnya.

Disetiap kolom provinsi pengguna harus menyelesaikan misi yaitu mencocokkan pasangan dari pakaian adat yang telah di sediakan, mencocokkan senjata adat dan rumah adat. Disetiap kolom provinsi diberi 3 kali kesempatan apabila terjadi kesalahan dalam mencocokkannya.

\section{Desain}

Desain proses dibuat berdasarkan kebutuhan fungsional dan kebutuhan data, Aliran Sistem digambarkan dengan menggunakan UML (Unified Modelling Language)

Diagram UML yang digunakan antara lain diagram use case, dan diagram sequence, Diagram use case menggambarkan fungsionalitas yang ditawarkan oleh sistem dan interaksi antara pengguna dengan sistem. Diagram sequence menggambarkan bagaimana objek saling berhubungan satu sama lain yang digambarkan sebagai rangkaian langkah-langkah yang dilakukan untuk menghasilkan keluaran tertentu.

\section{Use Case Diagram}

Use case diagram menggambarkan fungsionalitas yang diharapkan dari sebuah sistem. Use case menunjukan sebuah interaksi antara aktor dengan sistem. Komponen utama use case diagram ini adalah aktor dan use case. Pada aplikasi Ragam Budaya Nusantara ini pengguna bertindak sebagai aktor yang menjalankan sistem. Use case diagram ditunjukan oleh Gambar 2. berikut:

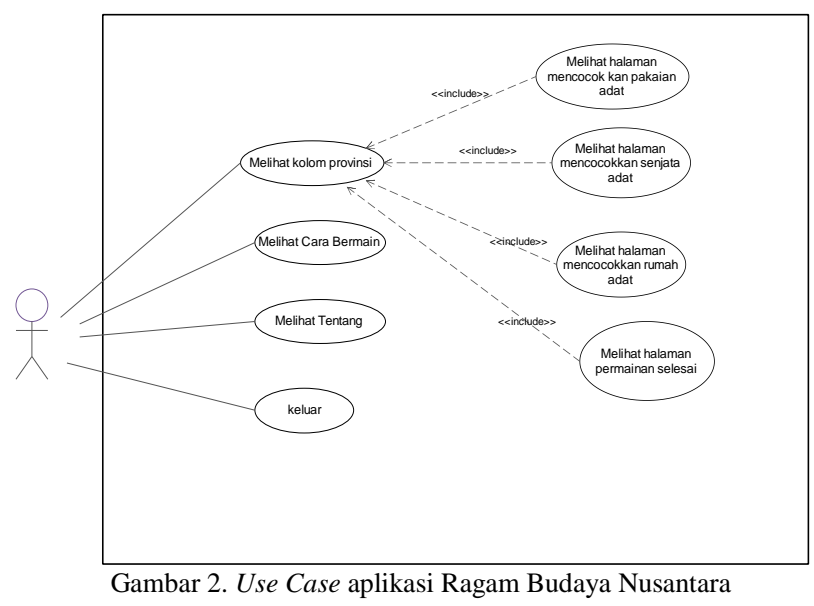

\section{Definisi Aktor}

Definisi Aktor berfungsi untuk mendeskripsikan peran aktor dalam aplikasi ini. Pada aplikasi yang akan dibangun ini hanya terdapat satu aktor yaitu pengguna. Pengguna merupakan Aktor yang berperan dalam menggunakan aplikasi yang dibuat pada tugas akhir ini.

\section{Definisi Use Case}

Definisi Use Case berfungsi sebagai penjelasan mengenai proses yang terdapat pada setiap use case. Definisi use case dari Tugas Akhir ini akan dijelaskan pada Tabel 3.1.

Tabel 1. Definisi Use Case

\begin{tabular}{|r|l|l|}
\hline No & Nama Use Case & Deskripsi \\
\hline 1 & Melihat mulai & $\begin{array}{l}\text { Pengguna mengakses menu mulai untuk } \\
\text { masuk ke dalam permainan }\end{array}$ \\
\hline
\end{tabular}




\begin{tabular}{|r|l|l|}
\hline 2 & $\begin{array}{l}\text { Melihat kolom } \\
\text { provinsi }\end{array}$ & $\begin{array}{l}\text { Pengguna mengakses menu kolom provinsi } \\
\text { untuk menentukan provinsi mana yang akan } \\
\text { dimainkan }\end{array}$ \\
\hline 3 & $\begin{array}{l}\text { Melihat } \\
\text { permainan }\end{array}$ & $\begin{array}{l}\text { Fungsionalitas akan menampilkan permaian } \\
\text { dari aplikasi Ragam Budaya Nusantara }\end{array}$ \\
\hline 4 & $\begin{array}{l}\text { Melihat halaman } \\
\text { mencocokkan } \\
\text { pakaian adat }\end{array}$ & $\begin{array}{l}\text { Fungsionalitas yang menampilkan pakaian } \\
\text { pakaiaan adat dan pengguna akan } \\
\text { mencocokkan pakaian yang benar }\end{array}$ \\
\hline 5 & $\begin{array}{l}\text { Melihat halaman } \\
\text { mencocokkan } \\
\text { senjata adat }\end{array}$ & $\begin{array}{l}\text { Fungsionalitas yang menampilkan senjata } \\
\text { adat dan pengguna akan mencocokkan } \\
\text { senjata yang benar }\end{array}$ \\
\hline 6 & $\begin{array}{l}\text { Melihat halaman } \\
\text { mencocokkan } \\
\text { rumah adat }\end{array}$ & $\begin{array}{l}\text { Fungsionalitas yang menampilkan rumah } \\
\text { adat dan pengguna akan mencocokkan } \\
\text { rumah yang benar }\end{array}$ \\
\hline 7 & $\begin{array}{l}\text { Melihat halaman } \\
\text { selesai }\end{array}$ & $\begin{array}{l}\text { Fungsionalitas yang menampilkan halaman } \\
\text { selesai dari permainan Ragam Budaya } \\
\text { Nusantara }\end{array}$ \\
\hline 8 & $\begin{array}{l}\text { Melihat cara } \\
\text { bermain }\end{array}$ & $\begin{array}{l}\text { Pengguna mengakses menu cara bermain } \\
\text { untuk mengetahui cara bermain dari } \\
\text { aplikasi Ragam budaya nusantara. }\end{array}$ \\
\hline 9 & $\begin{array}{l}\text { Pengguna mengakses menu tentang dan } \\
\text { akan menampilkan penjelasan dari aplikasi } \\
\text { Ragam Budaya Nusantara }\end{array}$ \\
\hline 10 & $\begin{array}{l}\text { Pengguna mengakses menu keluar dan } \\
\text { keluar dari aplikasi Ragam Budaya } \\
\text { Nusantara }\end{array}$ \\
\hline
\end{tabular}

\section{HASIL DAN PEMBAHASAN}

A. Hasil Pembuatan Aplikasi "Ragam Budaya Nusantara"

Pembuatan aplikasi ini menggunakan metodologi pengembangan multimedia yang sudah dijelaskan pada bab sebelumnya. Terdapat 6 tahapan yang dilakukan untuk menyelesaikan aplikasi ini, yaitu konsep, desain, pengumpulan materi, pembuatan, pengujian dan distribusi.

Pembuatan aplikasi ini diimplementasi berdasarkan perancangan yang telah dibahas pada Bab III, sehingga dihasilkan suatu permainan yang bekerja sesuai dengan fungsinya. Sedangkan pengujiannya dilakukan dengan metode black-box, serta akan dilakukan juga uji coba permainan secara langsung ke pengguna menggunakan kuesioner. Berikut ini merupakan tampilan aplikasi yang telah dibuat.

Gambar 3. menunjukkan tampilan menu utama dari aplikasi Ragam Budaya Nusantara

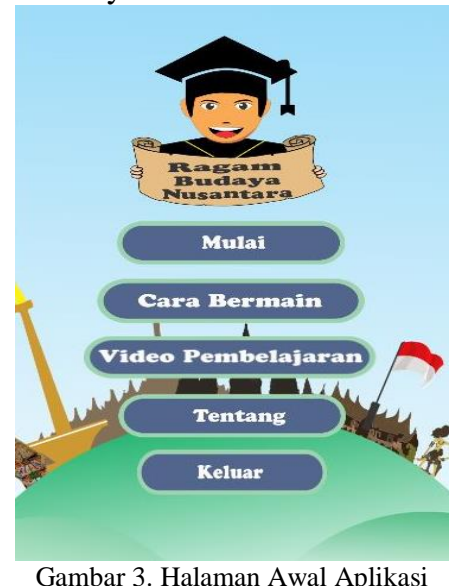

Selanjutnya gambar 4. menunjukkan tampilan pada menu mulai dari aplikasi Ragam Budaya Nusantara

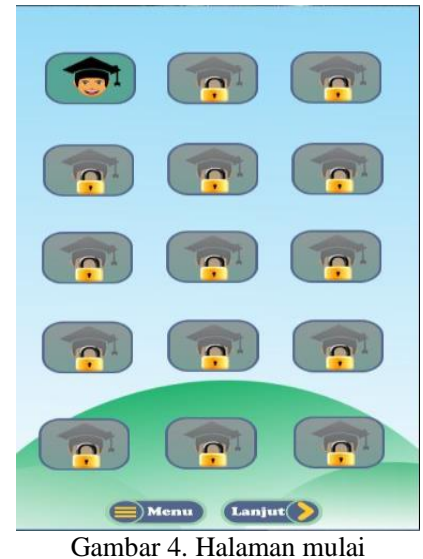

Gambar 5. menunjukkan tampilan pada permainan pakaian adat dari aplikasi Ragam Budaya Nusantara

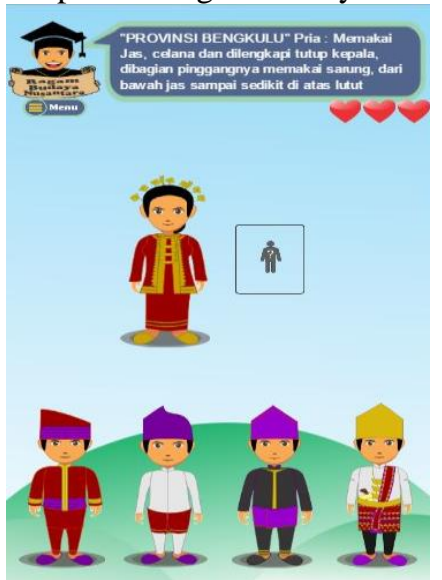

Gambar 5. Halaman permainan pakaian adat

Gambar 6. menunjukkan tampilan permainan pakaian senjata adat dari aplikasi Ragam Budaya Nusantara

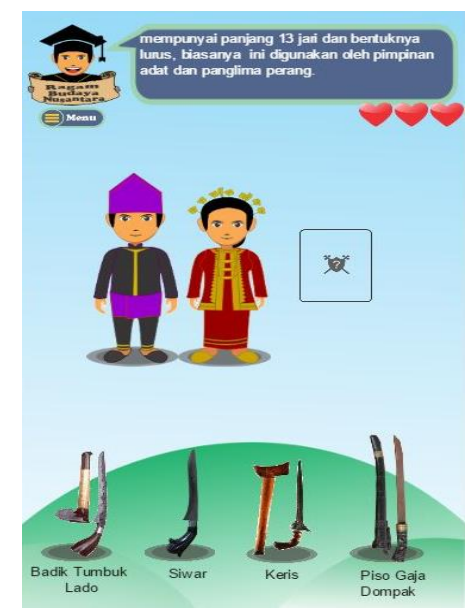

Gambar 6. Halaman permainan senjata adat

Gambar 7. menunjukkan tampilan permainan rumah adat dari aplikasi Ragam Budaya Nusantara 


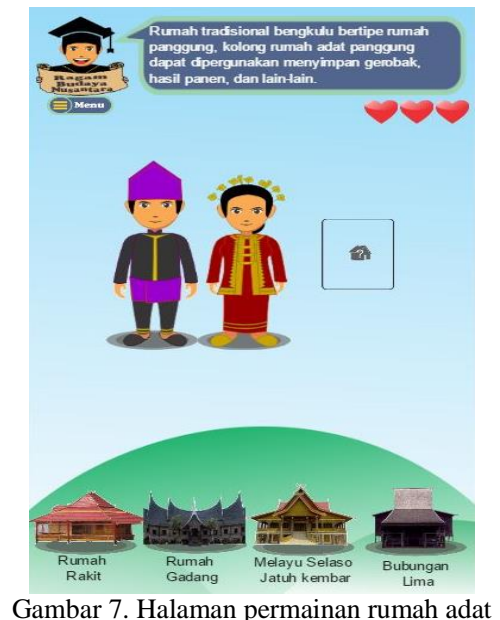

Gambar 8. menunjukkan tampilan pada permainan selesai dari aplikasi Ragam Budaya Nusantara

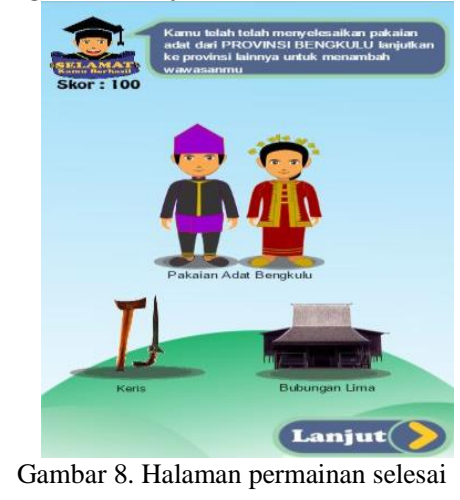

Selanjutnya pada gambar 9. menunjukkan tampilan ketika permainan gagal dari aplikasi Ragam Budaya Nusantara

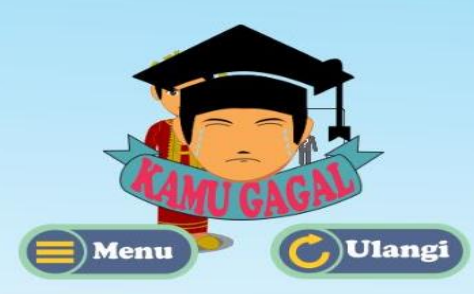

Gambar 9. Halaman permainan gagal

Pada gambar 10. menunjukkan tampilan ketika pengguna sudah menyelesaikan semua provinsi dari aplikasi Ragam Budaya Nusantara

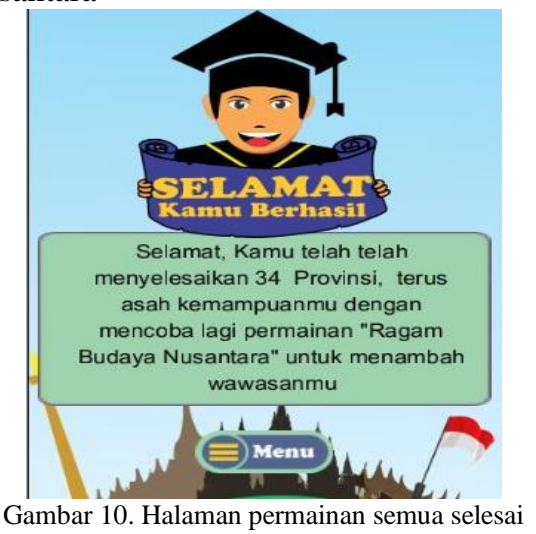

Gambar 11. menunjukkan tampilan menu cara bermain dari aplikasi Ragam Budaya Nusantara

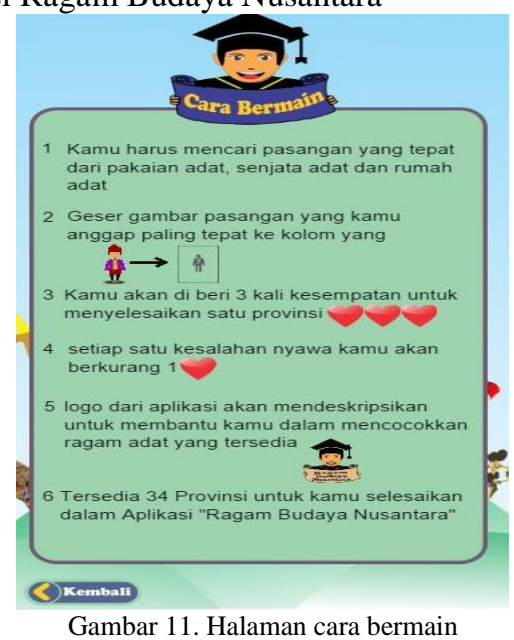

Pada gambar 12. menunjukkan tampilan menu tentang dari aplikasi Ragam Budaya Nusantara

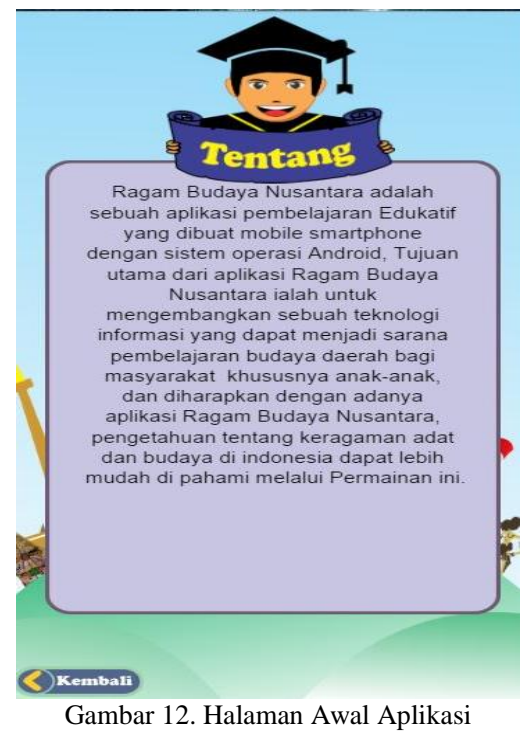

Pengujian Aplikasi dengan metode Black-box

Pengujian aplikasi "Ragam Budaya Nusantara" yang telah dibuat dalam penelitian ini dilakukan dengan menggunakan metode black-box. Tahapan pengujian ini berisi rangkaian pengujian tombol dan fungsi yang terdapat dalam aplikasi. Pengujian ini dilakukan untuk memeriksa fungsi yang terdapat dalam aplikasi, apakah hasilnya sesuai dengan yang diinginkan. Pengujian ini juga dilakukan untuk mengetahui apakah masih terdapat kesalahan dalam aplikasi ataukah masih terdapat kesalahan sehingga secepatnya dapat diberi solusi.

Pengujian dijalankan pada smartphone dengan sistem operasi android 4.3 Jellybean. Pengujian dilakukan dengan cara mengeksekusi souce code dan kemudian diamati apakah hasilnya sesuai dengan spesifikasi kebutuhan. Hasil dari pengujian aplikasi ditunjukkan dengan tabel-tabel pengujian black-box.

Berikut tabel pengujian pada fungsi umum aplikasi ditunjukkan oleh Tabel 2.

Tabel 2. Tabel Pengujian Fungsi Umum 


\begin{tabular}{|l|l|l|c|}
\hline Nama Pengujian & \multicolumn{1}{|c|}{$\begin{array}{c}\text { Bentuk } \\
\text { Pengujian }\end{array}$} & \multicolumn{1}{|c|}{ Hasil yang Diharapkan } & $\begin{array}{c}\text { Hasil } \\
\text { Pengujian }\end{array}$ \\
\hline Loading & $\begin{array}{l}\text { Membuka } \\
\text { aplikasi }\end{array}$ & $\begin{array}{l}\text { Tampilan icon loading } \\
\text { selanjutnya muncul halaman } \\
\text { awal }\end{array}$ & Berhasil \\
\hline $\begin{array}{l}\text { Pengujian menu } \\
\text { mulai }\end{array}$ & $\begin{array}{l}\text { Menyentuh } \\
\text { tombol mulai }\end{array}$ & Tampil halaman mulai & Berhasil \\
\hline $\begin{array}{l}\text { Pengujian menu cara } \\
\text { bermain }\end{array}$ & $\begin{array}{l}\text { Menyentuh } \\
\text { tombol cara } \\
\text { bermain }\end{array}$ & Tampil halaman cara bermain & Berhasil \\
\hline $\begin{array}{l}\text { Pengujian menu } \\
\text { tentang }\end{array}$ & $\begin{array}{l}\text { Menyentuh } \\
\text { tombol tentang }\end{array}$ & $\begin{array}{l}\text { Tampil halaman fungsi dan } \\
\text { kegunaan aplikasi "Ragam } \\
\text { Budaya Nusantara" }\end{array}$ & Berhasil \\
\hline $\begin{array}{l}\text { Pengujian menu } \\
\text { Keluar }\end{array}$ & $\begin{array}{l}\text { Menyentuh } \\
\text { tombol keluar }\end{array}$ & $\begin{array}{l}\text { Aplikasi keluar setelah } \\
\text { beberapa detik }\end{array}$ & Berhasil \\
\hline
\end{tabular}

Pengujian Aplikasi Menggunakan Kuesioner

Pengujian aplikasi dilakukan secara langsung kepada sasaran aplikasi, yaitu kepada masyarakat umum. Pengujian dilakukan secara obyektif dengan tujuan mengetahui penilaian terhadap aplikasi yang telah dibuat. Dalam pelaksanaannya aplikasi ini dijalankan oleh masing-masing pengguna, kemudian diberikan kuesioner kepada pengguna yang digunakan untuk mendapatkan data responden tentang penilaian aplikasi yang telah dibuat.

Setiap responden akan diberi 4 sampel pertanyaan dimana setiap pertanyaan terdapat 5 pilihan jawaban, yaitu Sangat Tidak Setuju (STS), Tidak Setuju (TS), Netral (N), Setuju (S), Sangat Setuju (SS). Masing-masing jawaban diberi skor berurutan sampai 5 .

Untuk mencari nilai persentase dari masing-masing jawaban kuesioner, digunakan rumus skala Likert sebagai berikut:

$$
Y=\frac{X}{\text { skor ideal }} \times 100 \%
$$

Keterangan : $\mathrm{X}$

= Jumlah frekuensi dikalikan dengan nilai kategori jawaban

Skor ideal = Nilai tertinggi dikalikan dengan jumlah sampel

$\mathrm{Y}=$ Nilai persentase yang dicari

Berikut ini adalah hasil persentase masing-masing jawaban yang sudah dihitung nilainya dengan menggunakan rumus di atas.

Pada Tabel 3. Dapat dilihat hasil kuesioner dari pertanyaan 1 "Aplikasi Ragam Budaya Nusantara sangat mudah dalam penggunaannya"

Tabel 3. Tabel Pengujian Kuesioner Pertanyaan 1

\begin{tabular}{|c|c|c|c|c|}
\hline Pertanyaan & Keterangan & Skor & Responden & Skor $\times$ Responden \\
\hline \multirow{3}{*}{1} & STS & 1 & 0 & 0 \\
\cline { 2 - 5 } & TS & 2 & 0 & 0 \\
\cline { 2 - 5 } & N & 3 & 0 & 0 \\
\cline { 2 - 5 } & S & 4 & 7 & 28 \\
\cline { 2 - 5 } & SS & 5 & 3 & 15 \\
\hline \multicolumn{7}{|c|}{ Jumlah } & 10 & 43 \\
\hline
\end{tabular}

Tabel 4. Dapat dilihat hasil kuesioner dari Pertanyaan 2 "Apakah aplikasi Ragam Budaya Nusantara ini sudah menyediakan media pembelajaran praktis dan menarik"

Tabel 4. Tabel Pengujian Kuesioner Pertanyaan 2

\begin{tabular}{|c|c|c|c|c|}
\hline Pertanyaan & Keterangan & Skor & Responden & Skor $\times$ Responden \\
\hline \multirow{3}{*}{2} & STS & 1 & 0 & 0 \\
\cline { 2 - 5 } & TS & 2 & 0 & 0 \\
\cline { 2 - 5 } & N & 3 & 0 & 0 \\
\cline { 2 - 5 } & S & 4 & 8 & 32 \\
\cline { 2 - 5 } & SS & 5 & 2 & 10 \\
\hline \multicolumn{5}{|c|}{ Jumlah } \\
\multicolumn{5}{|c|}{$Y=\frac{42}{10 \times 5} \times 100 \%=84 \%$} \\
\hline
\end{tabular}

Selanjutnya Tabel 5. Dapat dilihat hasil kuesioner dari Pertanyaan 3 "“Tampilan Aplikasi Ragam Budaya Nusantara secara keseluruhan bagus dan menarik"”,

Tabel 5. Tabel Pengujian Kuesioner Pertanyaan 3

\begin{tabular}{|c|c|c|c|c|}
\hline Pertanyaan & Keterangan & Skor & Responden & Skor $\times$ Responden \\
\hline \multirow{5}{*}{3} & STS & 1 & 0 & 0 \\
\hline & TS & 2 & 0 & 0 \\
\hline & $\mathrm{N}$ & 3 & 0 & 0 \\
\hline & $S$ & 4 & 7 & 28 \\
\hline & SS & 5 & 3 & 15 \\
\hline \multicolumn{3}{|c|}{ Jumlah } & 10 & 43 \\
\hline
\end{tabular}

Tabel 6. Dapat dilihat hasil kuesioner dari pertanyaan 4 "Apakah teks dalam permainan sudah jelas dan mudah dipahami"

\begin{tabular}{l} 
Tabel 6. Tabel Pengujian Kuesioner Pertanyaan 4 \\
\begin{tabular}{|c|c|c|c|c|}
\hline Pertanyaan & Keterangan & Skor & Responden & Skor $\times$ Responden \\
\hline \multirow{3}{*}{4} & STS & 1 & 0 & 0 \\
\cline { 2 - 6 } & TS & 2 & 0 & 0 \\
\cline { 2 - 6 } & N & 3 & 3 & 9 \\
\cline { 2 - 6 } & S & 4 & 6 & 24 \\
\cline { 2 - 5 } & SS & 5 & 1 & 5 \\
\hline
\end{tabular} \\
\hline
\end{tabular}


Pada Tabel 7. Dapat dilihat hasil kuesioner dari pertanyaan 5 "Apakah setelah menggunakan aplikasi Ragam Budaya Nusantara ini, anda lebih memahami pakaian adat, senjata adat, dan rumah adat"

Tabel 7. Tabel Pengujian Kuesioner Pertanyaan 5

\begin{tabular}{|c|c|c|c|c|}
\hline Pertanyaan & Keterangan & Skor & Responden & Skor $\times$ Responden \\
\hline \multirow{4}{*}{5} & STS & 1 & 0 & 0 \\
\cline { 2 - 5 } & TS & 2 & 0 & 0 \\
\cline { 2 - 5 } & N & 3 & 0 & 0 \\
\cline { 2 - 5 } & S & 4 & 5 & 20 \\
\cline { 2 - 5 } & SS & 5 & 5 & 25 \\
\hline \multicolumn{2}{|c|}{ Jumlah } & 10 & 45 \\
\hline
\end{tabular}

$$
Y=\frac{45}{10 \times 5} \times 100 \%=90 \%
$$

Pada Tabel 8. Dapat dilihat hasil kuesioner dari pertanyaan 6 "Apakah gambar dari pakaian adat, senjata adat dan rumah adat sudah jelas"

Tabel 8. Tabel Pengujian Kuesioner Pertanyaan 6

\begin{tabular}{|c|c|c|c|c|}
\hline Pertanyaan & Keterangan & Skor & Responden & Skor $\times$ Responden \\
\hline \multirow{4}{*}{6} & STS & 1 & 0 & 0 \\
\cline { 2 - 5 } & TS & 2 & 0 & 0 \\
\cline { 2 - 5 } & N & 3 & 0 & 0 \\
\cline { 2 - 5 } & S & 4 & 5 & 20 \\
\cline { 2 - 5 } & SS & 5 & 5 & 25 \\
\hline \multicolumn{2}{|c|}{ Jumlah } & 10 & 45 \\
\hline
\end{tabular}

$$
Y=\frac{45}{10 \times 5} \times 100 \%=90 \%
$$

Pada Tabel 9. Dapat dilihat hasil kuesioner dari pertanyaan 7 "Apakah aplikasi ini melengkapi materi belajar budaya daerah di sekolah"

\begin{tabular}{|c|c|c|c|c|}
\hline Pertanyaan & Keterangan & Skor & Responden & Skor $\times$ Responden \\
\hline \multirow{5}{*}{7} & STS & 1 & 0 & 0 \\
\hline & TS & 2 & 0 & 0 \\
\hline & $\mathrm{N}$ & 3 & 1 & 3 \\
\hline & S & 4 & 8 & 32 \\
\hline & SS & 5 & 1 & 5 \\
\hline \multicolumn{3}{|c|}{ Jumlah } & 10 & 40 \\
\hline
\end{tabular}

Tabel 9. Tabel Pengujian Kuesioner Pertanyaan 7

Pada Tabel 7. Dapat dilihat hasil kuesioner dari pertanyaan 8 "Apakah anda ingin menggunakan aplikasi Ragam Budaya Nusantara ini selanjutnya"

Tabel 7. Tabel Pengujian Kuesioner Pertanyaan 8

\begin{tabular}{|c|c|c|c|c|}
\hline Pertanyaan & Keterangan & Skor & Responden & Skor $\times$ Responden \\
\hline \multirow{3}{*}{8} & STS & 1 & 0 & 0 \\
\cline { 2 - 5 } & TS & 2 & 0 & 0 \\
\cline { 2 - 5 } & N & 3 & 1 & 3 \\
\cline { 2 - 5 } & S & 4 & 7 & 28 \\
\cline { 2 - 5 } & SS & 5 & 2 & 10 \\
\hline \multicolumn{5}{|c|}{ Jumlah } \\
\hline \multicolumn{5}{|c|}{$Y=\frac{41}{10 \times 5} \times 100 \%=82 \%$} \\
\hline
\end{tabular}

Pada Tabel 10. Dapat dilihat hasil kuesioner dari pertanyaan 9 "Apakah menu-menu dan tombol-tombol yang ada pada aplikasi ini dapat dengan mudah dibaca dan dipahami"

\begin{tabular}{l} 
Tabel 10. Tabel Pengujian Kuesioner Pertanyaan 9 \\
$\qquad$\begin{tabular}{|c|c|c|c|c|}
\hline Pertanyaan & Keterangan & Skor & Responden & Skor $\times$ Responden \\
\hline \multirow{3}{*}{9} & STS & 1 & 0 & 0 \\
\cline { 2 - 6 } & TS & 2 & 0 & 0 \\
\cline { 2 - 6 } & N & 3 & 0 & 0 \\
\cline { 2 - 6 } & S & 4 & 5 & 20 \\
\cline { 2 - 5 } & SS & 5 & 5 & 45 \\
\hline
\end{tabular} \\
\hline
\end{tabular}

Pada Tabel 11. Dapat dilihat hasil kuesioner dari pertanyaan 10 "apakah adan merasa bahwa aplikasi Ragam Budaya Nusantara ini lebih menarik daripada pelajaran di sekolah"

Tabel 11. Tabel Pengujian Kuesioner Pertanyaan 10

\begin{tabular}{|c|c|c|c|c|}
\hline Pertanyaan & Keterangan & Skor & Responden & Skor $\times$ Responden \\
\hline \multirow{3}{*}{10} & STS & 1 & 0 & 0 \\
\cline { 2 - 5 } & TS & 2 & 0 & 0 \\
\cline { 2 - 5 } & N & 3 & 1 & 3 \\
\cline { 2 - 5 } & S & 4 & 9 & 36 \\
\cline { 2 - 5 } & SS & 5 & 0 & 0 \\
\hline \multicolumn{6}{|c|}{ Jumlah } & 10 & 39 \\
\hline
\end{tabular}

Nilai hasil kuesioner juga ditampilkan dalam bentuk diagram batang untuk mempermudah dalam melakukan analisis. Berikut merupakan diagram batang hasil penilaian aplikasi Ragam Budaya Nusantara menggunakan kuesioner yang ditampilkan oleh Gambar 13.

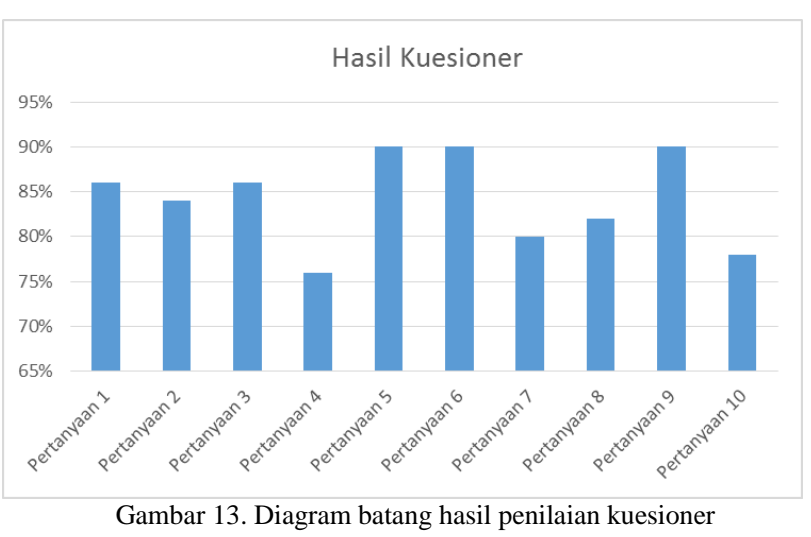




\section{B. Distribusi Permainan}

Agar banyak pengguna dapat memainkan permainan "Ragam Budaya Nusantara" ini, maka perlu dilakukan pendistribusian permainan. Tujuan dari pendistribusian permainan ini selain untuk menyebarkan permainan melalui jaringan juga untuk dapat menjadi sebuah evaluasi sehingga akan dapat mengembangkan sistem menjadi lebih baik lagi. Pendistribusian permainan ini dilakukan dengan mengupload file *.apk ke Google Play Store.

\section{Pembahasan}

Hasil pengujian aplikasi menggunakan metode black-box, menunjukkan bahwa permainan sudah berjalan sesuai dengan spesifikasi kebutuhan dan skenario aplikasi. Hal ini ditunjukkan oleh tabel 2 yang menampilkan hasil uji "Berhasil" pada tiap fungsi aplikasi dan tombol. Secara fungsional, aplikasi ini sudah dapat menghasilkan keluaran yang diharapkan.

Seperti dalam batasan masalah, bahwa permainan "Ragam Budaya Nusantara" ini akan dijalankan pada sistem operasi Android. Setelah dilakukan pengujian, permainan ini berjalan dengan baik pada android.

Berdasarkan hasil olah data kuesioner didapat skor ratarata dari semua pertanyaan yaitu sebesar $84 \%$. Keseluruhan dari hasil olah data kuesioner dapat disimpulkan bahwa aplikasi yang dibuat telah memenuhi syarat untuk dianggap baik.

\section{KESIMPULAN DAN SARAN}

\section{A. Kesimpulan}

Dari hasil pengujian dan analisis permianan edukatif Ragam Budaya Nusantara berbasis Android, dapat disimpulkan hal-hal yang diantaranya sebagai berikut.

1. Berdasarkan hasil pengujian aplikasi Ragam Budaya Nusantara menggunakan metode Black-box, seluruh fungsi menu yang ada dalam aplikasi telah berhasil sesuai dengan fungsinya.

2. Berdasarkan hasil pengujian aplikasi Ragam Budaya Nusantara menggunakan olahan data kuesioner menunjukkan bahwa $83 \%$ lebih responden menjawab dengan jawaban positif, atau dapat dikatakan aplikasi Ragam Budaya Nusantara sudah berhasil dengan baik. artinya lebih dari $80 \%$ responden menjawab dengan jawaban setuju dan sangat setuju. Rata-rata skor untuk seluruh hasil kuesioner adalah $87 \%$.

\section{B. Saran}

Saran yang dapat diberikan oleh penulis dalam upaya pengembangan aplikasi lebih baik lagi di kemudian hari adalah sebagai berikut.

1) Aplikasi "Ragam Budaya Nusantara" pakaian adat, senjata adat dan rumah adat, diharapkan dapat ditambah tarian adat dengan animasi bergerak.

2) Tampilan aplikasi "Ragam Budaya Nusantara" hanya diam dan statis, diharapkan dapat ditambah efek animasi sehingga membuat aplikasi ini semakin menarik.

\section{DAFTAR PUSTAKA}

[1] Abrar, S., Kliping Rumah Adat Indonesia beserta Penjelasannya, https://id.scribd.com/doc/89194466/rumah, 10 Desember 2014

[2] Augusra T.A, Alwie., Sistem Informasi Geografis Asrama Mahasiswa Aceh LBS (Location Based service) "Saweue Syedara", Skripsi S-1, Universitas Diponegoro, Semarang, 2014

[3] Setyani, F., Pengenalan Bahasa Inggris untuk anak melalui Permainan Edukasi "The Zoo" Berbasis Kinect, Skripsi S-1, Universitas Diponegoro, Semarang, 2013

[4] Hidayat, A., Siapa bilang anak sehat pasti cerdas, Jakarta, PT elex Media Komputindo, 2007.

[5] Hofstetter, F. T., Multimedia Literacy, 3rd Edition, Irwin/MCGrawHill, 2011.

[6] Ramadhan, Arief., Mengolah Audio dan MP3 dengan Audacity, Jakarta, PT Elex Media Komputindo, 2010.

[7] Seta, M.A., Adat dan Budaya 34 Provinsi di Indonesia. Jakarta, Laksana KIDZ, 2013.

[8] Supardi,Yuniar., Semua bisa jadi menjadi Programmer Android, Jakarta, PT Elex Media Komputindo, 2014.

[9] Sutardi, Tedi., Antropologi Mengungkap Keragaman Budaya, Bandung, PT Grafindo Media Pratama, 2007.

[10] Suyanto, M., Multimedia alat untuk meningkatkan keunggulan bersaing, Yogyakarta: Penerbit Andi offset, 2003.

[11] Syaputra, H, "Kewarganegaraan, Suku Bangsa, Agama, dan Bahasa sehari-hari Penduduk Indonesia”, Badan Pusat Statistik, Jakarta, 2011

[12] Permana, A.B.C., Perancangan Aplikasi Pengenal Alat Musik Tradisional "Gandara" Menggunakan MultiPoint Mouse SDK, Skripsi S-1, Universitas Diponegoro, Semarang, 2014.

[13] ---, Construct 2, http://www.scirra.com 03 September 2014

[14] ---, CorelDraw X6, http://graphicssoft.about.com 07 September 2014

[15] ---, Sound, http://Freesound.org, 2 Februari 2015

[16] ---, StatCounter Global stats, http://gs.statcounter.com/\#mobile_osID-monthly-201401-201412, 3 Januari 2015 